\title{
Langkah-Langkah Perencanaan Dalam Asuhan Keperawatan
}

\author{
Najla Asyah Syafawani Lubis/191101010
}

\author{
najlaasyahsyafawani@gmail.com
}

\section{Latar Belakang}

Rumah Sakit merupakan organisasi yang sangat kompleks dan juga komponen yang sangat penting dalam upaya peningkatan status kesehatan bagi masyarakat. Salah satu fungsi Rumah Sakit adalah menyelenggarakan pelayanan dan Asuhan Keperawatan yang merupakan bagian dari sistem pelayanan kesehatan dengan tujuan memelihara kesehatan masyarakat seoptimal mungkin. Rumah Sakit sebagai salah satu tatanan pemberian jasa pelayanan kesehatan harus mampu menyediakan berbagai jenis pelayanan kesehatan yang bermutu, institusi pelayanan kesehatan yang kompleks, padat karya, padat pakar dan padat modal (Ilyas, 2000).

Keperawatan merupakan profesi unik yang memiliki Fokus utama caring, yaitu Bagaimana memberikan dan mengelola asuhan Yang dibutuhkan pasien. Hal ini menjadikan perawat memiliki peran baik pemberi asuhan sebagai kemampuan klinis dan juga koordinator sebagai komponen manajerial. Peran perawat sebagai pemberi asuhan merupakan komponen penting yang esensial dalam sistem pemberian pelayanan kesehatan. kemampuan dan keterampilan perawat yang kuat dalam kepemimpinan dan administrasi sangat penting bagi pasien dan keselamatannya serta sistem layanan dan aksesnya. Mutu asuhan yang unggul dapat memenuhi kebutuhan masyarakat terhadap kesehatan. tuntutan tersebut membuat perawat perlu dipersiapkan dengan baik untuk membuat dan memproduksi pori strategi perubahan dan mengelola secara efektif koordinasi dan integrasi dari tim interdisipliner, kebutuhan masyarakat, dan sistem asuhan yang berkelanjutan (Rabelo et al, 2016). Itulah sebabnya, integrasi asuhan keperawatan dan manajemen keperawatan menjadi salah satu inti kompetensi yang dibutuhkan perawat untuk menjalankan peran dan fungsinya dalam lingkungan layanan asuhan kesehatan.

Manajemen keperawatan merupakan koordinasi dan integrasi dari sumber-sumber Keperawatan dengan menerapkan proses manajemen untuk mencapai tujuan, objektivitas asuhan keperawatan dan pelayanan keperawatan (Hubberd, 2000). proses manajemen dibagi dalam lima fase yaitu: 
planning, organizing, staffing, directing dan controlling yang merupakan satu siklus yang saling berkaitan satu sama lain (Siswanto, 2008).

Asuhan keperawatan merupakan Proses sistematis terstruktur, Dan integratif dalam Badan keilmuan keperawatan. asuhan ini diberikan melalui metode yang disebut proses keperawatan. proses keperawatan membantu perawat mendapatkan luaran, mengukur kualitas pelaksanaan asuhan keperawatan dan memudahkan perawat untuk melakukan praktik klinis keperawatan khususnya bagi perawat pemula (Xiao et al, 2017). proses keperawatan terdiri dari lima tahapan, yaitu pengkajian, diagnosis, perencanaan, implementasi, dan evaluasi.

Dokumentasi keperawatan merupakan unsur penting dalam sistem pelayanan kesehatan, karena dengan adanya dokumentasi yang baik informasi mengenai keadaan pasien dapat diketahui secara berkesinambungan. dokumentasi juga merupakan aspek legal tentang pembuatan asuhan keperawatan, cara lebih spesifik dokumentasi keperawatan dapat berfungsi sebagai sarana komunikasi antar profesi kesehatan, Sumber data untuk mengelola pasien dan penelitian serta sebagai barang bukti pertanggungjawaban dan pertanggunggugatan asuhan keperawatan serta sebagai sarana pemantau asuhan keperawatan.

\section{Metode}

Rancangan penugasan kajian ini menggunakan metode literatur review. Dimana metode ini dapat menyelesaikan suatu masalah dengan mengumpulkan data, menganalisa, membandingkan sehingga dapat menentukan pengambilan keputusan dalam masalah tersebut yang berdasarkan dari penjelasan sumber dan referensi yaitu berupa jurnal, ebook atau buku teks.

\section{Hasil}

Proses keperawatan meliputi pengkajian keperawatan, diagnosa keperawatan, perencanaan keperawatan, implementasi keperawatan dan evaluasi keperawatan. berdasarkan hasil penelitian Buheli, 2012. menunjukkan sebagian besar perawat (80,4\%) melakukan pengkajian keperawatan dan (19,6\%) perawat yang masih kurang dalam melakukan pengkajian keperawatan, untuk diagnosa keperawatan terdapat $(60,8 \%)$ yang sudah melakukan diagnosa keperawatan dengan baik dan (39,2\%) perawat yang masih kurang dalam melakukan diagnosa keperawatan. dalam melaksanakan perencanaan keperawatan terdapat $(74,5 \%)$ perawat yang sudah melakukan bukan 
perencanaan Keperawatan dengan cukup dan (25,5\%) yang masih kurang dalam melaksanakan perencanaan keperawatan. untuk implementasi keperawatan terdapat $(74,5 \%)$ perawat yang sudah melaksanakan implementasi keperawatan dan (25,5\%) yang masih kurang dalam melaksanakan implementasi keperawatan. Sedangkan untuk evaluasi keperawatan terdapat $(60,8 \%)$ perawat yang sudah melaksanakan evaluasi Keperawatan dengan cukup dan $(39,2 \%)$ yang masih kurang dalam melaksanakan evaluasi keperawatan.

Berdasarkan hasil penelitian Supratti dan Ashriady, 2016. Menunjukkan bahwa pendokumentasian keperawatan Berdasarkan kelengkapan perencanaan keperawatan di RSUD Kabupaten Mamuju yang masuk dalam kategori kurang lengkap yaitu 46 perawat (49,5\%). hal ini berbeda dengan hasil penelitian yang dilakukan Hartati, dkk. 2010. dengan judul Analisis Kelengkapan Dokumentasi Proses Keperawatan Pasien Rawat Inap di RSU PKU Muhammadiyah Gombong Jawa Tengah. hasil penelitian tersebut menunjukkan bahwa status pasien yang telah dikaji terlihat pendokumentasian tahap perencanaan mendapatkan skor 59\% (kategori cukup), akan tetapi masih ada beberapa aspek yang belum memenuhi standar asuhan keperawatan.

Berdasarkan hasil penelitian Koerniawan, dkk 2020. menunjukkan bahwa sebagian besar dokumentasi keperawatan telah terdokumentasi dengan lengkap dan tepat (skor 4) pada aspek intervensi yang direncanakan mampu mengatasi etiologi diagnosis sebanyak 35 dokumen $(33,3 \%)$. Selain itu, sebagian besar dokumentasi juga telah terdokumentasi namun sebagian tepat (skor 3) pada aspek intervensi yang direncanakan kongkrit/aktual/nyata/jelas sesuai NIC serta mengandung apa yang akan dilakukan, bagaimana, seberapa sering, dan siapa yang melakukannya sebanyak 51 dokumen $(48,6 \%)$, dan pada aspek intervensi yang telah dilakukan didokumentasikan dengan lengkap sebanyak 39 (37,1\%). Berdasarkan penelitian Murni, dkk 2016. hasil pengamatan di rawat inap dokumentasi asuhan keperawatan berisi, pengkajian $47 \%$, diagnosis keperawatan 54\%, perencanaan 47\%, tindakan keperawatan 49\% dan evaluasi $50 \%$. dari data tersebut tanpa lah pelaksanaan pendokumentasian asuhan keperawatan masih rendah (49,5\%) sedangkan yang ditetapkan Depkes 80\%. RSUD Pariaman menggunakan standar asuhan keperawatan 65\%. Hal ini menunjukkan bahwa dokumentasi Asuhan Keperawatan yang berkesinambungan belum terlaksana dengan baik. 


\section{Pembahasan}

Pelayanan keperawatan merupakan bagian integral dari pelayanan kesehatan yang menjadi cermin keberhasilan pelayanan kesehatan di Rumah Sakit. upaya peningkatan mutu pelayanan di Rumah Sakit tidak bisa lepas dari upaya peningkatan mutu pelayanan keperawatan. pelayanan keperawatan dalam pelaksanaannya merupakan Praktek Keperawatan yaitu tindakan Mandiri perawat profesional dalam memberikan Asuhan Keperawatan yang dilaksanakan dengan cara kerjasama yang bersifat kolaboratif dengan klien dan tenaga kesehatan lainnya sesuai dengan lingkup wewenang dan tanggungjawabnya (Sulistyowati, 2012).

Proses keperawatan adalah suatu cara atau metode yang sistematis dalam memberikan asuhan keperawatan yang dilakukan oleh perawat dan bekerjasama dengan pasien (induvidu, keluarga, masyarakat) yang bertujuan untuk mengidentifikasi masalah keperawatan dengan melakukan pengkajian, menentukan diagnosa, merencanakan tindakan yang akan dilakukan, melaksanakan tindakan serta mengevaluasi hasil asuhan keperawatan yang telah diberikan dengan berfokus pada pasien, berorientasi pada tujuan yang telah ditetapkan bersama. Menurut Craven dan Hirnle bahwa proses keperawatan memiliki enam fase yaitu: pengkajian, diagnosa, tujuan, rencana tindakan, implementasi, dan evaluasi. Orientasi dari pelayanan asuhan keperawatan adalah pada pencapaian tujuan asuhan keperawatan. Asuhan keperawatan baru dapat dikatakan berhasil dan selesai jika semua tujuan asuhan keperawatan yang telah ditetapkan dalam perencanaan keperawatan telah tercapai. Berdasarkan pendapat dari beberapa ahli tentang tahapan dalam proses keperawatan, tahap dimulai dengan: tahap pengkajian, tahap diagnosa keperawatan, tahap perencanaan, tahap pelaksanaan serta tahap evaluasi.

\section{Pengkajian keperawatan}

Pengkajian keperawatan adalah tahap awal dari proses keperawatan dan merupakan suatu proses yang sistematis dalam pengumpulan data dari berbagai sumber data untuk mengevaluasi dan mengidentifikasi status kesehatan klien.Pengkajian keperawatan merupakan dasar pemikiran dalam memberikan asuhan keperawatan sesuai dengan kebutuhan klien. Pengkajian yang lengkap, dan sistematis sesuai dengan fakta atau kondisi yang ada pada klien sangat penting untuk merumuskan suatu diagnosa keperawatan dan dalam memberikan asuhan keperawatan sesuai dengan respon individu. 


\section{Diagnosa keperawatan}

Diagnosa keperawatan merupakan suatu pertanyaan yang menggambarkan respons manusia (keadaan sehat atau perubahan pola interaksi actual/potensial) dari individu atau kelompok.Diagnosa keperawatan merupakan penilaian klinis tentang respons individu, keluarga, atau komunitas terhadap masalah kesehatan atau proses kehidupan actual ataupun potensial sebagai dasar pemilihan intervensi keperawatan untuk mencapai hasil tempat perawat bertanggung jawab. Tujuan diagnosis keperwatan adalah memungkinkan sebagai perawat untuk menganalisis dan mensintesis data yang telah dikelompokkan, selain itu diagnosis keperawatan digunakan untuk mengidentifikasi masalah, factor penyebab masalah, dan kemampuan klien untuk dapat mencegah atau memecahkan masalah.

Langkah-langkah dalam menentukan diagnosa keperawatan adalah :

1.) Pertama Anda harus melakukan klasifikasi data. Klasifikasi data adalah aktivitas pengelompokakan data-data klien atau keadaan tertentu tempat klien mengalami permasalahan kesehatan atau keperawatan berdasarkan kriteria permasalahannya. Klasifikasi ini berdasarkan pada kebutuhan dasar manusia yang dikelompokkan dalam data subjektif dan data objektif.

2. ) Kedua Anda harus membuat Interpretasi Data, Anda bertugas membuat interpretasi atas data yang sudah dikelompokkan dalam bentuk masalah keperawatan atau masalah kolaboratif.

3.) Ketiga Anda harus Menentukan Hubungan Sebab Akibat, Dari masalah keperawatan yang telah Anda tentukan kemudian, Anda harus menentukan factor-faktor yang berhubungan atau faktor risiko yang menjadi kemungkinan penyebab dari masalah yang terjadi. Kemungkinan penyebab harus mengacu pola kelompok data yang sudah ada.

4.) Keempat Anda harus Merumuskan Diagnosis Keperawatan, Perumusan diagnosis keperawatan yang Anda buat didasarkan pada pola identifikasi masalah dan kemungkinan penyebab. 


\section{Perencanaan Keperawatan}

Perencanaan adalah pengembangan strategi desain untuk mencegah, mengurangi, dan mengatasi masalah- masalah yang telah diidentifikasi dalam diagnosis keperawatan. Desain perencanaan menggambarkan sejauh mana Anda mampu menetapkan cara menyelesaikan masalah dengan efektif dan efisien. Tipe Rencana Tindakan Keperawatan terdiri dari:

\section{1) Diagnostik/Obserevasi}

Rencana tindakan keperawatan diagnostik adalah rencana tindakan untuk mengkaji atau melakukan observasi terhadap kemajuan klien dengan pemantauan secara langsung yang Anda lakukan secara kontinu. Dengan observasi ini, diharapkan hal-hal yang Anda tetapkan dalam kriteria hasil dapat Anda pantau secara berkesinambungan sampai tujuan berhasil dicapai.

\section{2) Terapeutik/Nursing Treatment}

Rencana tindakan keperawatan terpeutik adalah rencana tindakan yang ditetapkan untuk mengurangi, memperbaikidan mencegah perluasan masalah.Rencana tindakan ini berupa intervensi mandiri Anda yang bersumber dari ilmu, kiat dan seni keperawatan. Dalam suatu masalah keperawatan, biasa didapatkan beberapa (lebih dari satu) alternatif penyelesaian masalahnya, Anda dituntut untuk dapat memilih mana yang paling sesuai untuk Anda tetapkan pada pasien.

3) Penyuluhan /Health Education/Pendidikan Kesehatan

Rencana tindakan keperawatan yang berbentuk pendidikan kesehatan adalah rencana tindakan yang Anda tetapkan bertujuan untuk meningkatkan perawatan diri kilen dengan penekanan pada partisispasi klien untuk betanggung jawab terhadap perawatan diri, terutama untuk perawatan dirumah. Penyuluhan atau pendidikan kesehatan diperlukan, terutama bila masalah keperawatan dan kriteria hasil berhubungan dengan aspek kognitif, afektif, dan psikomotor. Penyuluhan yang Anda lakukan dapat berbentuk penyuluhan umum tentang segala sesuatu tentang penyakit dan perawatan klien atau juga lebih spesifik sesuai dengan masalah yang terjadi. 


\section{4) Rujukan atau Kolaborasi atau Medical Treatment}

Rencana tindakan keperawatan kolaboratif adalah tindakan medis yang dilimpahkan kepadaAnda. Rencana kolaboratif ini disesuaikan dengan masalah yang terjadi. Masalah yang bersifat kognitif, afektifdan psikomotor mungkin tidak memerlukan tindakan medis. Namun, untuk masalah yang berhubungan dengan perubahan fungsi tubuh, sering memerlukan rencana kolaboratif.

4. Intervensi keperawatan atau pelaksanaan keperawatan

Intervensi keperawatan atau pelaksanaan keperawatan Intervensi keperawatan atau pelaksanaan keperawatan adalah realisasi rencana tindakan untuk mencapai tujuan yang telah Anda tetapkan. Kegiatan dalam pelaksanaan juga meliputi pengumpulan data berkelanjutan, mengobservasi respon klien selama dan sesudah pelaksaan tindakan, serta menilai data yang baru. Intervensi keperawatan dibuat untuk mencapai tujuan dan kriteria hasil yang diharapkan guna mengatasi etiologi dan menyelesaikan masalah keperawatan. Intervensi dibuat secara spesifik dan operasional yang terdiri dari aktivitas apa yang akan dilakukan, bagaimana, seberapa sering, dan lebih baik lagi jika teridentifikasi siapa apa yang melakukan. prinsip tersebut perlu dilakukan supaya tiap perawat yang melihat perencanaan keperawatan mudah untuk melakukannya atau mengaplikasikan rencana tersebut. setelah tindakan telah dilakukan, tiap intervensi dievaluasi berdasarkan respon pasien terhadap tindakan yang telah diimplementasikan dan mengacu atau berorientasi pada kriteria hasil yang telah ditetapkan (Abdelkader, Othman, 2017).

\section{Evaluasi Keperawatan}

Pengertian Evaluasi adalah penilaian dengan cara membandingkan perubahan keadaan pasien (hasil yang diamati) dengan tujuan dan kriteria hasil yang Anda buat pada tahap perencanaan. Tujuan diadakan rencana tindakan keperawatan, untuk memodifikasi rencana tindakan keperawatan serta meneruskan rencana tindakan keperawatan. Evaluasi pada dasarnya dilakukan untuk mengetahui apakah tujuan yang ditetapkan sudah dicapai atau belum. Oleh karena itu, evaluasi dilakukan sesuai dengan kerangka waktu penetapan tujuan (evaluasi hasil), tetapi selama proses pencapaian terjadi pada klien juga harus selalu harus dipantau (evaluasi 
proeses).Untuk memudahkan mengevaluasi atau memantau perkembangan klien, digunakan komponen SOAP/ SOAPIE/SOAPIER.

\section{Kesimpulan}

Keperawatan merupakan suatu bentuk pelayanan profesional bersifat humanistik menggunakan pendekatan holistik, dilakukan berdasarkan ilmu dan kiat keperawatan, berorientasi pada kebutuhan objektif klien. Praktek Keperawatan mengacu pada standar profesional keperawatan dan menggunakan etika keperawatan sebagai tuntunan utama perawat dituntut untuk selalu melaksanakan Asuhan Keperawatan yang benar atau rasional.

Proses asuhan keperawatan merupakan tugas dan kewajiban seorang perawat dari pasien datang sampai pasien pulang dimulai dengan pengkajian secara menyeluruh, kemudian menegakkan diagnosa keperawatan dari data pengkajian tersebut, serta melaksanakan intervensi, implementasi dan evaluasi keefektifan diagnosa awal yang sudah ditegakkan (Nursalam, 2007).

\section{Daftar Pustaka}

Aini, N. (2018). Model Keperawatan beserta aplikasinya dalam keperawatan. Malang: Universitas Muhammadiyah Malang.

Anggeria, E., \& Maria. (2018). Hubungan Supervisi Dengan Pelaksanaan asuhan Keperwatan Di Ruang Rawat Inap Lantai 10 Rumah Sakit Umum Royal Prima Medan. Jurnal JUMANTIK, 3 (2), 78-97.

Budiono \& Sumirah, B, P.(2016). Konsep Dasar Keperawatan (Ed 2). Jakarta. Bumi Medika.

Buheli, K. (2012). Faktor Yang Mempengaruhi Kinerja Perawat Dalam Penerapan Proses Keperawatan Di RSUD Toto Kabupaten Bone Bolango. Jurnal Sainstek, 6 (5).

Butar-Butar, J., \& Simamora, R. H. (2016). Hubungan Mutu Pelayanan Keperawatan dengan Tingkat Kepuasan Pasien Rawat Inap di RSUD Pandan Kabupaten Tapanuli Tengah. Jurnal Ners Indonesia, 6(1), 50-63. 
Haryanti, T., Pujianto, T, I., \& Adinatha, N, N. (2013). Analisis Pengaruh Persepsi Perawat Pelaksana Tentang Fungsi Manajerial Kepala Ruangan Terhadap Pendokumentasian Asuhan Keperawatan Di Ruang Rawat Inap Rumah Sakit Swasta Di Semarang. Jurnal Managemen Keperawatan, 1 (2), 131-137.

Koerniawan, D., Daeli, N, E., \& Srimiyati. (2020). Aplikasi Standar Proses Keperawatan: Diagnosis, Outcome, Dan Intervensi Pada Asuhan Keperawatan. Jurnal Keperawatan Silampari, 3 (2), 739-751.

Murni, D., Bachtiar, H., \& Sasmita, H. (2016). Kajian Faktor Organisasi Dengan Kinerja Perawat Pelaksana Dalam Pendokumentasian Asuhan Keperawatan Di Ruang Rawat Inap RSUD Pariaman. Ners Jurnal Keperawatan, 12 (1), 1-14.

Novieastari, E., Gunawijaya, J., \& Indracahyani, A. (2018). Pelatihan Asuhan Keperawatan Peka Peka Budaya Efektif Meningkatkan Kompetensi Kultural Perawat. Jurnal Keperawatan Indonesia, 21 (1), 27-33.

Simamora, R. H. (2005). Hubungan Persepsi Perawat Pelaksana Terhadap Penerapan Fungsi Pengorganisasian Yang Dilakukan Oleh Kepala Ruangan Dengan Kinerjanya Diruang Rawat Inap RSUD Koja Jakarta Utara (Doctoral dissertation, Tesis FIK UI, Tidak dipublikasikan).

Supratti., \& Ashriady. (2016). Pendokumentasian Standar Asuhan Keperawatan Di Rumah Sakit Umum Daerah Mamuju, Indonesia. Jurnal Kesehatan Manarang, 2 (1), 44-51.

Wulandini, P., Krianto,T., \& Priwahyuni, Y. (2016). Faktor-Faktor Yang Berhubungan Dengan Pendokumentasian Asuhan Keperawatan Di Rumah Sakit Jiwa. Ners Jurnal Keperawatan, 12 (2), 131-142. 